\title{
JUSTYNA SPRUTTA Eucharystia w ikonie „Trójca Święta” Andrzeja Rublowa
}

Najbardziej znanym dzielem mnicha A. Rublowa (1360-1370 r.) jest ikona „Trójca Święta”, datowana na lata ok. 1422-1437, uznana przez zwolany w Moskwie w 1551 r. Sobór Stu Rozdzialów jako wzorzec dla ikonopisów, gdy chodzi o ikonografię Trójcy Świętej ${ }^{1}$. Ten należący do zbiorów Galerii Tretiakowskiej w Moskwie wizerunek posiada wymiary: $142 \times 114 \mathrm{~cm}$.

Andrzej Rublow napisal tę ikonę na zamówienie opata monasteru TroickoSergiejewskiego, Nikona. Nikon zlecil w 1422 r. zarówno A. Rublowowi jak też jego przyjacielowi, Danielowi Czarnemu, ozdobienie ikonostasu w odnowionym monasterze pod wezwaniem Trójcy Świętej. Praca nad ikonostasem trwala od 1422 do 1426 r. Zlecenie namalowania ikony „Trójca Święta” wiązało się z uczczeniem w ten sposób przez opata Nikona pamięci żyjącego w XIV w. św. Sergiusza z Radoneża, założyciela Ławry Troickiej (obecnie Sergiejew Posad w pobliżu Moskwy), który to klasztor stal się ośrodkiem duchowego promieniowania na Ruśs. Należy tutaj dodać, że św. Sergiusz z Radoneża w centrum swojej

\footnotetext{
${ }^{1}$ Por. G. B u n g e: Trójca Rublowa. Thum. K. Mały s. Kraków 2003 s. 11, 20; J. F o r e s t: Modlitwa $z$ ikonami. Thum. E. E. Now a k ow s k a. Bydgoszcz 1999 s. 148; S. B a b o lin: Ikona Swiętej Trójcy Rublowa. Od przedwiecznej Rady do Uczty eucharystycznej. Thum. F. Mi c ki e w i c z. „Communio". Wydanie polskie. R. 20: $2000 \mathrm{nr} 2$ s. 11; Por. także - I. J a z y k o w a: Świat ikony. Thum. H. P a p r o c ki: Warszawa 2003 s. 98; P. Ev dok i mo v: Sztuka ikony. Teologia piękna. Thum. M. Ż u row s a Warszawa 1999 s. 205; P. E v do k i mo v: Prawostawie. Thum. J. K 1 ing e r. Warszawa 2003 s. 249; G. B ung e: Inny Paraklet [Ikona Trójcy Świętej mnichamalarza Andrzeja Rublowa]. Tłum. K. Ma 1 y s. Kraków 2001 s. 38.

${ }^{2}$ Por. B. S t a n d a e r t: Ikona Trójcy Andrieja Rublowa. Thum. K., M. B i e 1 a w s c y. Bydgoszcz 2002 s. 10-12; H. J. M. Nou we n: Ujrzéc piękno Pana modlac się z ikonami. Thum. J. W ę c 1 a w i k. Warszawa 1998 s. 16; E. S m y k o w s k a: Ikona [Maly slownik]. Warszawa $2002 \mathrm{~s}$. 81; P. E v d o k i mo v: Sztuka ikony. Teologia piekna, dz. cyt., s. 204. Szerzej- G. B u n g e: Inny Paraklet [Ikona Trójcy Świętej mnicha-malarza Andrzeja Rublowa], dz. cyt., s. 63-68.
} 
pobożności umieścił kontemplację Trójcy Świętej, będącej w prawosławiu fundamentem myśli religijnej, kultu i duchowego doświadczenia ${ }^{3}$.

Ikona „Trójca Święta” Andrzeja Rublowa objawia Tajemnicę trzech Osób Boskich, Tajemnice jedności i zarazem troistości Boga. Stanowi ona typ ikonograficzny „Gościnność Abrahama” (znany już wcześniej w sztuce bizantyjskiej) ${ }^{4}$, który nawiązuje do biblijnego opowiadania o przybyciu do Abrahama trzech Wędrowców, o którym to wydarzeniu mówi Księga Rodzaju (1, 1-15). Jednakże w ikonie „Trójca Święta” A. Rublow pominal postaci Abrahama, jego żony Sary jak i sługi zabijającego cielca na ucztę, cielca, który jako zwierzę ofiarne w Starym Testamencie, stanowiace zarazem typ Zbawiciela, zostal uwzględniony w tym wizerunku ${ }^{5}$. Ikonopisarz ten nie umieścil $\mathrm{w}$ swoim dziele również suto zastawionego stołu, koncentrując się tylko i wylącznie na Teofanii.

Nieobecność na ikonie postaci Abrahama czy Sary można w rezultacie zinterpretować jako przejęcie na siebie gościnności Ảbrahama przez kontemplującego ikonę ${ }^{6}$. Tym samym każdy chrześcijanin kontemplujący daną ikonę udziela gościny przychodzacemu do niego Bogu Trójosobowemu. Goszcząc Ojca, Syna i Ducha, zostaje on wlączony do wspólnoty trzech Osób Boskich, wspólnoty koncentrującej się wokól stohu-ołtarzu, stołu-ziemi, stołu-Ewangelii, na którym to stole znajduje się kielich eucharystyczny. Zatem komunia Boga z czlowiekiem ma za swoje centrum Eucharystię. Kierowane ku czlowiekowi zaproszenie do wejścia $\mathrm{w}$ tẹ boska wspólnote sugeruje też występujaca w ikonie A. Rublowa tzw. odwrócona perspektywa ${ }^{7}$. Czlowiek wchodzi w Bożą rzeczywistość, by w towarzystwie Boga Trójosobowego spożyć Ciało i Krew Jezusa Chrystusa, którego typem jest wspomniany już cielec $w$ kielichu umieszczonym na stoleoltarzu.

Kielich ten jest jedynym elementem znajdującym się na stole, jednakże nie zawsze taka sytuacja miała miejsce, gdy chodzi o wschodnią ikonografię Trójcy

${ }^{3}$ H. J. M. N o u w e n pisze: Święty Sergiusz, na którego cześć Rublow namalowal ikonę Trójcy Świętej, chcial wszystkich Rosjan skupić wokól Imienia Bożego, aby przez kontemplację Trójcy Swiętej mogli pokonać nienawiść pożerajaca świat [H. J. M. N o u w e n: Ujrzeć piękno Pana modlac sie z ikonami, dz. cyt., s. 23. Por. J. F or e s t: Modlitwa $z$ ikonami, dz. cyt., s. 148. P. E v d o k i mo v: Sztuka ikony. Teologia piękna, dz. cyt., s. 204. Szerzej - G. B u n g e: Inny Paraklet [Ikona Trójcy Świętej mnicha-malarza Andrzeja Rublowa], dz. cyt., s. 69-72.

${ }^{4}$ I. J a z y k ow a: Swiat ikony, dz. cyt., s. 92.

${ }^{5}$ Por. G. B u n g e: Trójca Rublowa, dz. cyt., s. 24-25; J. F o r e s t: Modlitwa z ikonami, dz. cyt., s. 148

${ }^{6}$ Kontemplujacy ikonę staje się na wzór A b r a h a m a i S a r y czcicielem Mysterium Trinitatis. Por. G. B ung e: Inny Paraklet [Ikona Trójcy Swiętej mnicha malarza Andrzeja Rublowa], dz. cyt., s. 84.

${ }^{7}$ Por. J. F or e s t: Modlitwa z ikonami, dz. cyt., s. 150; M. Qu e no t: Ikona. Okno ku wieczności. Thum. H. P a p r o c ki. Białystok 1997 s. $89,93$. 
Świętej. Np. mozaika z VI w. z San Vitale w Rawennie, w scenie „Gościnności Abrahama", ukazuje na stole trzy okragłe bochenki chleba naznaczone litera „X” wskazująca na Jezusa Chrystusa. Ponadto, na brązowych drzwiach cerkwi pw. Narodzenia Maryi w Suzdalu z XIII w., w scenie przedstawiajacej „Gościnność Abrahama", na stole znajdują się nie tylko trzy jednakowe bochenki chleba, ale również trzy kielichy, z których środkowy jest wyraźnie większy; chodzi tutaj prawdopodobnie o kielich przykryty pateną ${ }^{8}$. Uwage zwracają też trzy bliźniaczo podobne oblicza Aniolów oraz znajdujące się na pólmisku niepodzielone zwierzę ofiarne. Występujące w omawianej ikonografii potrójne powtórzenia, np. symbolu czy litery, wskazują na popularny od starożytności sposób przedstawiania Misterium Trinitatis.

W dziele Odkupienia uczestniczą zatem - jak i w mającej miejsce w Kościele bezkrwawej Ofierze Jezusa Chrystusa - trzy Osoby Boskie. W dziejach typu ikonograficznego „Gościnność Abrahama” podkreślana jest jedność tychże Osób przez umieszczenie ich na tym samym poziomie tudzież nadanie im tej samej wielkości, ale także akcentowana jest hierarchiczność Trójcy Świętej przez ukazanie centralnej postaci jako górującej nad pozostalymi postaciami. Identyfikacja tychże uczestników uczty eucharystycznej nie jest jednoznaczna. Istnieje tutaj kilka interpretacji. Pierwsza z nich, najbardziej zresztą prawdopodobna i równie popularna, postrzega w środkowej postaci Osobę Jezusa Chrystusa, natomiast po lewej stronie - patrząc na ikonę - Ojca, zaś po prawej - Ducha Świętego. W tej interpretacji na Osobę Odkupiciela wskazuje nie tylko umieszczony w tyle za Jej plecami dąb z Mamre, odnoszacy się m. in. do krzyża Chrystusowego, rozumiany ponadto jako zasadzone przez Boga w Raju drzewo życia, przy którym dokonal się upadek Prarodziców i z którego to drzewa zostal zbudowany krzyż Odkupiciela, ale również kolor szat Jezusa Chrystusa, którego niebieski plaszcz wskazuje na Jego Bóstwo, natomiast czerwona tunika $z$ dodatkiem purpury - na Jego naturę ludzka, jak i na godność królewską. Na boskość Slowa Wcielonego wskazuje też złoty pas umieszczony na tunice. Tak interpretowana ikona „Trójca Święta" A. Rublowa zawiera w sobie wizję posłuszeństwa Syna względem Ojca i pragnienia pelnienia Jego woli. Wskazuje na to także nieco wyżej od prawego uniesione lewe kolano Jezusa Chrystusa, wyrażając gotowość Syna do wstania i wypelnienia misji powierzonej Mu przez Ojca. Centralne miejsce, jakie zajmuje w wizerunku Osoba Zbawiciela dowodzi prawdy, iż Wcielenie stało się najważniejszym wydarzeniem $w$ historii zbawienia, uzyskując - zgodnie $\mathrm{z}$ myśla prawoslawną - swoje dopelnienie w Misterium Odkupienia ${ }^{9}$. W ikonie tej po lewej stronie zasiada Ojciec odziany w przezroczyste, duchowe szaty w kolorze niebieskim i czerwonym. Po stronie prawej miejsce przy stole zajmuje Duch Święty,

\footnotetext{
${ }^{8}$ Por. I. J a z y k ow a: Świat ikony, dz. cyt., s. 91-92; G. B ung e: Inny Paraklet [Ikona Trójcy Swiętej mnicha-malarza Andrzeja Rublowa], dz. cyt., s. 20, 24, 29.

${ }^{9}$ Por. W. L o s s ki: Teologia dogmatyczna. Thum. H. P a p r o c k i. Białystok 2000 s. $73-76$.
} 
odziany w szatę niebieska, akcentujaca Jego boskość, oraz w szatę zieloną, której zielony kolor symbolizuje m.in. odnowę, odrodzenie, przemianę. Samo rozmieszczenie tych postaci, patrząc od strony lewej do prawej, odpowiada porząkowi występujacemu m. in. w Symbolu wiary: „Wierzę w Boga Ojca (...), Syna (...) i Ducha Swiętego (...)"10. Gdy chodzi natomiast o druga interpretację, w środkowej postaci postrzega się Ojca, Źródło wszelkiego bytu, zaś w umieszczonym za Jego plecami dębie - drzewo zasadzone przez Niego w Raju (Rdz 2, 9). Po prawej stronie od Ojca - zgodnie ze slowami z Listu do Rzymian $(8,34)$ : Chrystus Jezus, który ponióst [za nas] śmierć, co więcej-zmartwychwstat, siedzi po prawicy Boga - zasiada Syn. Bóg Ojciec zwraca się ku Synowi, gdyż wypowiada się w Nim. Syn mówi o Sobie w Ewangelii wedlug świętego Jana (14, 10; 16, 15): Ja jestem w Ojcu, a Ojciec we Mnie (...). Wszystko, co ma Ojciec, jest moje. Ojciec blogosławi kielich, ofiarowując go Synowi, za którego plecami znajduje się budowla interpretowana jako Kościól, mający za „kamień węgielny” (por. Ef 2, 20) samego Jezusa Chrystusa (Mt 21, 42). Gdy chodzi o tę interpretacje postrzegajaca w centralnej postaci Boga Ojca, po którego prawej stronie zasiada Syn, jej zwolennicy powolują się na świadectwo św. Stefana z Permu, wspólczesnego A. Rublowowi, który przywiózl na swoją misje wśród Zyrian ikonę „Trójca Święta"11. W ikonie tej przy postaci znajdujacej się po lewej stronie - patrząc na wizerunek - widnieje napis oznaczajacy Syna, natomiast przy postaci zajmującej miejsce po prawej stronie napis wskazujący na Ducha Świętego, zaś w centrum wizerunku, przy środkowej postaci, napis: „Ojciec”" ${ }^{\text {. Postać }}$ pierwszej Osoby Boskiej odziana w ikonie Andrzeja Rublowa w niebieski plaszcz i czerwona, z domieszką purpury, tunikę, może odzwierciedlać prawdę, że nikt nie może zbliżyć się do Ojca inaczej, jak tylko w Jezusie Chrystusie. Przedmiot niniejszej refleksji stanowi jednak bardziej popularna, częściej spotykana w publikacjach osób zajmujących się problemem ikony, pierwsza interpretacja.

W ikonie „Trójca Święta” A. Rublowa, przy stole ze znajdującym się na nim kielichem, zasiadaja trzy postaci o takich samych obliczach, ale o odmiennym stroju, z takimi samymi rabdosami w rękach symbolizujacymi posłannictwo jak i wladzę duchowa, w których to rabdosach P. Evdokimov postrzega berla, ${ }^{13}$. Ich glowy są ku sobie nieco pochylone, ponadto Postaci te lączą się lekko ze soba, niejako przeplywając jeden w drugiego - taka wizja akcentuje jedność Trójcy Świętej.

${ }^{10}$ Por. M. Quenot: Zmartwychwstanie i ikona. Thum. H. Paprocki. Bialystok 2001 s. 207.

11 Por. P. E v d ok i m o v: Sztuka ikony. Teologia piękna, dz. cyt., s. 207; I. J a z y k ow a: Swiat ikony, dz. cyt., s. 92-93; G. B u ng e: Inny Paraklet [Ikona Trójcy Swiętej mnicha malarza Andrzeja Rublowa], dz. cyt., s. 42.

${ }^{12}$ P. E v d o k i m o v: Sztuka ikony. Teologia piękna, dz. cyt., s. 207-208.

${ }^{13}$ Tamże, s. 207. 
Ci trzej Aniolowie wpisani sa w zasugerowany w ikonie okrag, symbolizujacy ich wieczność, doskonalość, jedność ${ }^{14}$. W centrum tego okręgu znajduje się wykonujaca gest blogosławieństwa ręka Jezusa Chrystusa. W okręgu tym panuje także ruch obejmujący nie tylko Osoby Boskie, ale ogarniajacy również świat w celu przemienienia go Bożymi energiami w sacrum, rzeczywistość oddaną Bogu, a skupioną wokól Oltarza ${ }^{15}$. Duch Święty kieruje się mianowicie ku Synowi zasiadającemu w centrum wizerunku, natomiast Syn kieruje się ku Ojcu, oddając Mu w swej Ofierze w sposób pełny cale stworzenie. Spojrzenie Ojca, w którego rękach zbiega się wszystko i który jest Poczattkiem wszystkiego poleca kontemplującemu ikonę Ducha, którego Ojciec - na co wskazuje teologia prawoslawna - posyła. Ten obecny w ikonie „Trójca Święta” A. Rublowa ruch wpisany jest także w trójkat równoramienny - figurę wskazująca na Boga Trójosobowego. Łacząc krańce stohu-oltarza, miejsca Ofiary Jezusa Chrystusa, z punktem umieszczonym nad głową środkowej postaci, dostrzega się, że wszystkie trzy postaci usytuowane zostaja w trójkącie równoramiennym, wskazującym na jedność i równość Osób Boskich ${ }^{16}$.

Do eucharystycznego wymiaru ikony A. Rublowa odsyla w sposób szczególny zasugerowany w tej ikonie krzyż, stanowiący niewidzialna, ale oczywistą oś kompozycji. Aureola wokól glowy Jezusa Chrystusa, kielich i znak ziemi, jakim jest stól-oltarz, sytuuja się na tej samej linii pionowej, dzielącej ikonę na dwie części, która to linia przecina się z linią horyzontalna, lacząca aureole pozostałych postaci: Ojca i Ducha. Tym samym tworzy się krzyż wpisany w święty krag życia Osób Boskich, do którego to kręgu szczególnie przez ujęty w danej ikonie sakrament Eucharystii zostaje zaproszony czlowiek. Krzyż ten - zdaniem P. Evdokimova - jest żywq osiq milości Trójcy Świętej ${ }^{17}$, gdyż Ojciec jest miłościq, która daje krzyż, Syn jest milościq ukrzyżowanq, Duch Święty jest krzyżem milości, jego niezwyciężona mocq ${ }^{18}$. Ten sam ruch, który dotyczy w ikonie A. Rublowa Osób Boskich, ogarnia również obejmujace caly wszechświat ramiona krzyża. W Ewangelii wedlug św. Jana Jezus Chrystus tak mówi o Sobie: $A J a$, gdy zostanę nad ziemię wywyższony, przyciagnę wszystkich do Siebie $(\mathrm{J} 12,32)$.

Na wymiar eucharystyczny ikony „Trójca Święta” w szczególny sposób wskazuje nie tylko krzyż zasugerowany w tym wizerunku, ale również kielich

\footnotetext{
${ }^{14}$ Tamże, s. 209-210

${ }^{15}$ Por. B. S t a n d a er t: Ikona Trójcy Andrieja Rublowa, dz. cyt., s. 19-20; P. E v dok imo v: Sztuka ikony. Teologia piękna, dz. cyt., s. 207.

${ }^{16}$ P. E v d ok i m o v: Sztuka ikony. Teologia piękna, dz. cyt., s. 209; D. F o r s t n e r: Świat symboliki chrześcijańskiej [Leksykon]. Tłum. W. Zakrzewska, P. P a c h c i arek, R. Tur z y ń s k i. Warszawa 2001 s. 59.

${ }^{17}$ P. E v d o k i m o v: Sztuka ikony. Teologia piękna, dz. cyt., s. 209.

${ }^{18}$ Tamże.
} 
umieszczony na stole-oltarzu ${ }^{19}$, w którym to kielichu znajduje się cielec ofiarny. Poza tym w ikonie tej występuje także niewidzialny, również zasugerowany kielich, w którego centrum (zgodnie z pierwszą interpretacją obrazu) zasiada Jezus Chrystus ${ }^{20}$.

Gdy chodzi o kielich widzialny, zobrazowana jest nad nim blogoslawiąca ręka Odkupiciela, której trzy złączone palce wskazują na trzy Osoby Boskie, natomiast dwa pozostale - na naturę boską i ludzka w Osobie Jezusa Chrystusa. W kierunku kielicha spogląda zarówno Bóg Ojciec jak i Duch Święty. Podczas gdy prawa dłoń Ducha Swiętego kieruje się ku temu kielichowi, Ojciec gestem ręki niejako podaje kielich Synowi, wyrażając w danym geście poslannictwo drugiej Osoby Boskiej. W Ewangelii wedlug świętego Jana Zbawiciel tak mówi o swej misji: Czyż nie mam pić kielicha, który Mi podal Ojciec? (J 18, 11). Jezus Chrystus dzięki gestowi prawej ręki wskazuje na Dar ze Swego życia i zarazem skierowanym ku Ojcu spojrzeniem wyjaśnia, że czyni wszystko z miłości do Ojca. Właśnie w tym geście miłości Ojciec znajduje upodobanie. Caly wszechświat partycypuje w tej wielkiej wymianie milości mającej miejsce między trzema Osobami Boskimi, zaś centrum tego wszechświata stanowi stojący na stoleoltarzu kielich eucharystyczny. Z kielicha tego spożywają chrześcijanie każdego czasu i każdej przestrzeni, by mieć życie wieczne, a Uczta ta dokonuje się w obecności Ojca, Syna i Ducha.

Pierwotna zawartość kielicha w danej ikonie stanowił cielec, Baranek Boży zabity przed założeniem świata (por. Ap 13,8), jednakże w późniejszym czasie w miejscu cielca namalowano na wizerunku kiść winogron ${ }^{21}$. Ten dodany motyw nie pozostawal jednak w sprzeczności z duchem Eucharystii (aczkolwiek w pewnym stopniu przeczyl opowiadaniu o wizycie trzech Wędrowców u Abrahama). $\mathrm{Na}$ eucharystyczną symbolikę kiści winogron wskazuje m.in. D. Forstner pisząc, że sok z winogron, postać Krwi Chrystusa, napetnia kielich, który Kościól sklada w ofierze Bogu, konsekrowane wino jest symbolem, które rzeczywiście jest tym, co oznacza: Bożym napojem życia ${ }^{22}$.

Wizja cielca w kielichu umieszczonym na stole odsyla do wizji Jezusa Chrystusa jako Żertwy w jeszcze jednym występująym w ikonie „Trójca Święta” kielichu - niewidzialnym, o którym już wspomniano. Ten niewidzialny kielich

${ }^{19}$ B. S t a n d a e r t: Ikona Trójcy Andrieja Rublowa, dz. cyt., s. 23.

${ }^{20}$ T. Š p i d lík, M. I. R u p n i k: Mowa obrazów. Thum. J. D e m b sk a. Warszawa 2001 s. 34;. Ikona Swiętej Trójcy Rublowa. Od przedwiecznej Rady do Uczty eucharystycznej. Tlum. F. M i c k i e w i c z. "Communio". Wydanie polskie. R. 20: 2000 nr 2 s. 15.

${ }^{21}$ Por. B. S t a n d a e r t: Ikona Trójcy Andrieja Rublowa, dz. cyt., s. 23; Ikona Świętej Trójcy Rublowa. Od przedwiecznej Rady do Uczty eucharystycznej. Tłum. F. Mi c k i e w i c z. „Communio". Wydanie specjalne. R. 20:2008 nr 2 s. 11.

${ }^{22}$ D. F o r s t n e r: Świat symboliki chrześcijańskiej [Leksykon], dz. cyt., s. 180-181. 
uformowany jest z linii zewnetrznych obu zasiadajacych po bokach Jezusa Chrystusa Postaci - Ojca i Ducha. Zbawiciel natomiast znajduje się wewnątrz tego kielicha, wykonując w nim znak blogoslawieństwa, skierowany ku światu również włączonemu w tenże kielich.

Kielich widzialny umieszczony jest na stole, który często interpretuje się jako oltarz. Na funkcję stołu jako oltarza wskazuje nie tylko znajdujący się na nim kielich eucharystyczny, ale również prostokątna wnęka widoczna w zwróconej ku kontemplującemu ikonę stronie stolu. Wnęka ta też podkreśla funkcję stolu jako oltarza. Należy w tym miejscu dodać, że od dawna we wschodniej stronie oltarza istniał otwór shużacy do przechowywania relikwii, a niekiedy także Eucharystii. Ta prostokątna wnęka w oltarzu wskazuje, że jest to zwrócona w przeciwnym kierunku względem ludu wschodnia strona miejsca Ofiary Jezusa Chrystusa. Oznacza to, że Ojciec i Duch zasiadaja za oltarzem, natomiast Jezus Chrystus jako Arcykaplan przed nim, zwrócony ku wschodowi, podobnie jak i ziemski kaplan (np. prawoslawny) przy skladaniu bezkrwawej Ofiary ${ }^{23}$. Prostokat stolu-ołtarza interpretowany jest jako kamień węgielny ołtarza, na którym dokonuje się Ofiara Odkupiciela i w którym to oltarzu znajdują się relikwie świętych. Jeszcze inna interpretacja w stole tym postrzega grób Jezusa Chrystusa, z którego wychodzi, wstępując do Ojca. Zatem w ikonie „Trójca Święta” A. Rublowa stól staje się oltarzem, sam natomiast wizerunek jest jak gdyby odbiciem eucharystycznej celebracji. Należy tutaj dodać, że Eucharystię często sprawowano na grobach męczenników.

Symbolika stolu nie kończy się na jego interpretacji jako oltarza, wokól którego koncentruje się nie tylko ziemska, ale jak wynika z ikony A. Rublowa także niebiańska Liturgia. W prostokątnym kształcie stolu dostrzega się także hieroglif kosmosu; stól ten symbolizuje również Ziemię. Podróżnik z VI w., Kosmas Indikopleustes w dziele zatytulowanym Chrześcijańska topografia wszechświata utrzymuje, że Ziemia ma ksztalt dlugiego kwadratu ${ }^{24}$. W tym prostokacie symbolizującym ziemię zagłębia się korzeniami dąb z Mamre, drzewo życia, Krzyż. Ku ziemi kierują się także dłonie Osób Boskich. Syn blogosławi, a Duch Święty w geście ręki niejako unosi się nad światem, co odsyla nas do Jego unoszenia się nad wodami przed stworzeniem świata (por. $\mathrm{Rdz} 1,2$ ). Dlonie postaci dą̇ą ku ziemi, będącej miejscem realizacji Bożej Miłości, Miłości uwydatnionej w szczególny sposób w Ofierze Zbawiciela. Prostokątny blat stołu wskazuje także

${ }^{23}$ Por. G. B ung e: Trójca Rublowa, dz. cyt., s. 16; Ikona Świętej Trójcy Rublowa. Od przedwiecznej Rady do Uczty eucharystycznej. Tłum. F. Mi c k i e w i c z. „Communio”. Wydanie polskie. R. 20: $2000 \mathrm{nr} 2$ s. 13; G. B ung e: Inny Paraklet [Ikona Trójcy Swiętej mnicha-malarza Andrzeja Rublowal, dz. cyt., s. 81, 96.

${ }^{24}$ P. E v d o k i m o v: Sztuka ikony. Teologia piękna, dz. cyt., s. 208. Por. Ikona Świętej Trójcy Rublowa. Od przedwiecznej Rady do Uczty eucharystycznej, dz. cyt., s. 13; P. E v d o k i m o v: Prawostawie, dz. cyt., s. 250. 
na cztery strony świata, uchodzace w dobie Ojców Kościola za szyfr czterech Ewangelii, dlatego blat ten jest również symbolem powszechności Slowa ${ }^{25}$.

W tej eucharystycznej ikonie, jaką jest „Trójca Święta” A. Rublowa, nie bez znaczenia są także takie elementy kompozycji, jak wspomniana już budowla, drzewo i góry. Drzewo Mamre zostalo już ukazane, gdy chodzi o jego symbolikę występująca w tym wizerunku. Warto natomiast zatrzymać się pokrótce nad znaczeniem budowli i gór. Za postacią Ducha Świętego widoczny jest zarys skal. Stanowią one tutaj obraz wzlotu ducha ku niebosiężnym wyżynom, ku niestworzonemu, przemieniajacemu profanum w sacrum światlu z góry Tabor. Skaly te przywoluja na myśl tradycję nie tylko biblijna, ale i monastyczna, łączaca w sobie, zarówno góry jak i pustynię, proroków, jak i mężów Bożych, wodę i Ducha $^{26}$. Ukazany na tle gór Duch Święty kieruje się ku kontemplującemu ikonę, gdyż to On wprowadza czlowieka we wspólnotę z Bogiem, upodabniając go do Syna. Czlowiek zostaje zatem przez trzecią Osobę Boską odesłany do Jezusa Chrystusa stanowiacego Jedno z Ojcem i będącego zarazem Jego Obrazem, Ikona. Za postacia Boga Ojca znajduje się natomiast budowla interpretowana jako „,dom Ojca”, w którym ,jest mieszkań wiele", na co wskazuje Ewangelia wedhug świętego Jana $(14,2)$, lub jako Kościól otwarty na Żydów i pogan ${ }^{27}$.

W ikonie „Trójca Święta” A. Rublowa istnieją zatem trzy nakladające się na siebie wymiary ${ }^{28}$. Pierwszy wymiar - to reminiscencja biblijnego opisu wizyty trzech Wędrowców u Abrahama. Pominięcie w tej ikonie postaci Abrahama, jego żony Sary, slugi, zachęca do przejścia do drugiego wymiaru - wymiaru Bożej ekonomii. W tym wymiarze trzej Wędrowcy są rozumiani jako Osoby Boskie, namiot Abrahama interpretuje się natomiast jako świątynię, dąb z Mamre - jako drzewo życia, czyli krzyż, „drzewo życia”, które jest „miłością Trójcy Świętej, drzewem, z którego spadł Adam", jak stwierdza św. Izaak, zaś góry jako wyżyny, ku którym wznosi się w Bogu duch ludzki, ale także jako schematyczny przekrój natury, znak jej obecności, tudzież cielca na półmisku - jako pokarm

${ }^{25}$ P. Evdoki mov: Sztuka ikony. Teologia piękna, dz. cyt., s. 208. Por. D. F o r stner: Swiat symboliki chrześcijańskiej [Leksykon], dz. cyt., s. 60; P. E v d o k i m o v: Prawoslawie, dz. cyt., s. 250-251.

${ }^{26}$ Skałe można tutaj rozumieć także jako symbol ziemi odnawianej przez Ducha Świętego, na której dopelnia On dziela Syna aż do Jego drugiej paruzji. Ponieważ skała ta pierwotnie posiadała „szczeline”" odnosi się do skaly rozszczepionej laską Mojż esza, z której to skaly wytrysnęla woda „żywa" dla spragnionego ludu Izraela. W tym drugim znaczeniu skała ta symbolizuje J e z u s a C h ry st u s a (por. 1 Kor 10,4). Sam Zbawiciel odnosi strumienie wody zywej do Ducha Świętego. Por. G. B un g e: Trójca Rublowa, dz. cyt., s. 42-43; G. T e n ż e: Inmy Paraklet [Ikona Trójcy Swiętej mnicha-malarza Andrzeja Rublowa], dz. cyt., s. 91, 93, 99.

${ }^{27}$ Por. J. F or e s t: Modlitwa z ikonami, dz. cyt., s. 150. Por. Ikona Świętej Trójcy Rublowa. Od przedwiecznej Rady do Uczty eucharystycznej, dz. cyt., s. 13.

${ }^{28}$ P. E v d o k i m o v: Sztuka ikony. Teologia piękna, dz.cyt., s. 205-206. Por. T e nż e: Prawostawie, dz. cyt., s. 249. 
ustępujacy miejsca kielichowi eucharystycznemu. T. Špidlík pisze: gest gościnności Abrahama z ikony »Trójca tradycja Kościola wiq̨ze z symbolem wyzwolenia, czyli z aniolem Wyjścia. A stól Abrahama staje się w tej ikonie także stolem eucharystycznym. Oznacza to, że milość jest wymiana darów, w której czlowiek ofiaruje Bogu to, co znajduje w stworzeniu, a Bóg z powrotem daje mu to samo stworzenie objawione w jego prawdzie. Czlowiek ofiarowuje chleb, a w zamian otrzymuje chleb prawdziwy, ten, dzięki któremu, gdy go spożywa, nie umrze $(\ldots)^{29}$. Wydlużone proporcje trzech postaci wskazują w tym drugim wymiarze na sięganie poza czasoprzestrzeń, natomiast skrzydla symbolizują bliskość tego, co niematerialne, niezależność od doczesności, uduchowienie. Przedmiotem realizującej się w ikonie rozmowy trzech Osób Boskich jest milość i plynący z niej Dar, który stanowi Syn jako Znak i Objawienie miłości Boga do stworzenia. Ostatni, trzeci wymiar jest wymiarem wewnatrz-boskim: ekonomia zbawienia wyplywa bowiem $z$ wewnętrznego życia Boga, istnienia opartego na milości.

Na zakończenie należy wskazać także na słowa Jana Pawła II, który w swej Encyklice zatytulowanej Ecclesia de Eucharistia vivit podkreśla eucharystyczny wymiar ikony „Trójca Święta” Andrzeja Rublowa: Splendor architektury i mozaik na chrześctjańskim Wschodzie i Zachodzie jest powszechnym dziedzictwem wierzqcych i niesie $w$ sobie życzenie, powiedzialbym rękojmię, upragnionej petnej komunii w wierze i w celebracji. Zaklada to i wymaga, aby Kościól byl glęboko eucharystyczny - jak na slynnej ikonie »Trójcy Swiętej" Rublowa, na której dzielenie się tajemnica Chrystusa $w$ lamanym chlebie jest jakby zanurzone $w$ niezglębionej jedności trzech Osób Boskich - czyniąc samego siebie ikonq Trójcy Świętej ${ }^{30}$.

${ }^{29}$ T. Š pidlík, M. I. R u pn ik: Mowa obrazów, dz. cyt., s. 25.

${ }^{30} \mathrm{~J}$ an Pawel I I: Encyklika Ecclesia de Eucharistia vivit. Watykan 2003 nr 50. Por. T e n ż e: List apostolski Mane nobiscum Domine. Watykan $2004 \mathrm{nr} 11$. 